DOI $10.4467 / 2543733$ XSSB.17.026.8324

\title{
THE POLITICAL, ECONOMIC AND CULTURAL INFLUENCES OF NEO-OTTOMANISM IN POST-YUGOSLAVIAN COUNTRIES. AN ANALYSIS ILLUSTRATED WITH SELECTED EXAMPLES
}

Key words: neo-Ottomanism, Islamic terrorism, Turkish policy, post-Yugoslavian countries, religious fundamentalism, the Balkans, economic influence, Islamization.

An ideology of neo-Ottomanism, which has become part of the Turkish foreign policy in the 21 st century, dates back to the period of the rule of the Ottomans in the Balkans. However, it is difficult to distinguish Islamization from the influence of Turkish factors, but other Muslim countries are also active in the Balkans, for example, Saudi Arabia or Iran. In the 21st century, Muslim inspirations in many areas of life are noticed in Bosnia and Herzegovina, Albania, Kosovo, Macedonia, Montenegro, Serbia (and in the strict sense in Bulgaria and Greece).

The goal of this analysis was to show expansion of Turkish policy, defined as neo-Ottomanism, in post-Yugoslavian countries, and its effect in the spheres of political, economic and cultural life. Therefore, the following question must be asked: do Turkish influences contribute to the specific culture of European Islam, of which goal, despite prevailing Islamophobia, is to disseminate ideals of tolerance between nations and religions? Does the Turkish capital contribute only to the economic development of post-Yugoslavian countries through investments? On the other hand, the reactivation of neo-Ottomanism may contribute to the development of radical tendencies, including religious fundamentalism, which is, in many aspects, pose a threat to post-Yugoslavian countries. More and more researchers and political experts claim that the political situation in the Balkans can be destabilized as a result of the domination of the Muslim environment, whereas the dissemination of radical versions of this religion such as Wahhabism ${ }^{1}$ may favour the

${ }^{1}$ Wahhabis - radical Islamic group from Saudi Arabia (18th century). It propagates superiority of Islam over other religions. Wahhabis in the western Balkans appeared during the civil war, causing tensions in moderate community of Yugoslavian Muslims. 
development of Islamic terrorism ${ }^{2}$. Serbian researchers have a critical approach to this issue and they claim that neo-Ottomanism is of revisionist a nature, because it disturbs the political balance in the western Balkans resulting from the Dayton Agreement $(1995)^{3}$. According to Serbian researchers, the development of these tendencies may lead to deep and dangerous political changes. Darko Tanasković paid attention to the fact that Turkey, by activating in its former historical base (hinterland), gives itself the right to historical responsibility for the situation in the Balkans. Therefore, it is suspected that their goal may be new imperial order - "PAX Ottomana"4.

\section{Islamization of the Balkans as a result of the Turkish policy of conquests}

The small Turkish emirate established at the close of 13 th century by the emir Osman (1291-1326)gave rise to the future empire, the goal of which was to revive the Byzantine Empire in order to dominate the world. The unique state structure - combining political and cultural (religious) contrasts of the territories belonging to the legacy of in the strict sense both the East and the West, Europe and Asia -was one of the main factors allowing the survival of the Padishah state for over 500 years $^{5}$.

Osman's successor - Orhan, taking advantage of crisis in the sultanate of Konya and the struggle for power in the Byzantine Empire, took actions that decided about the dynamics of the development of the Padishah Empire. He conquered Bithynia and Gallipoli (1354), which enabled him to control the Bosphorus Strait and the Dardanelles, giving a chance for the invasion of the Balkan Peninsula ${ }^{6}$. In 1362, the army of Padishah captured Adrianople, where the state capital was moved to three years later ${ }^{7}$. Other spectacular victories of the Ottomans included: defeating the coalition of the troops of Balkan countries at the Maritsa River near the village of Chernomen (1371) and in Kosovo (1389), con-

2 There are many theses and articles about Muslim fundamentalism and terrorism, among others: Ch. D e1 is o, The coming Balkan Caliphate: the threat of radical Islam to Europe and the West, Westport, Connecticut London 2007; D. G i b a s-Krza k, Bośnia i Hercegowina: determinanty dziejów. Pomiędzy Serbami, Chorwatami a supremacją Muzułmanów, Częstochowa 2016; S. Ra du 1j, Terroristička mreža u Bosni, Beograd 2007; H. Efendić, Mudžahedini u Bosni, Sarajevo 2007; I. Mlivončić, Al Qaida se kalila u Bosni i Hercegovini. Mjesto i uloga mudžahida u republici Hrvatskoj i Bosni i Hercegovini od 1991. do 2005. godine, Split-Mos$\operatorname{tar}$ 2007; D. Galija š ević, Era terorizma u BiH, Beograd 2007; J. E1säs s e r, Jak dżihad przybyt do Europy. Wojownicy Boga i tajne stużby na Bałkanach, Warszawa 2007; I. S t a w o w y-K a w k a, Miejsce ludności muzułmańskiej w Macedonii - przemiany i perspektywy, „Prace Komisji Środkowoeuropejskiej PAU”, 2014, Vol. XXII.

${ }^{3}$ Serbian historiography pays attention to destructive role of Muslim religion and Pan-turkish ideology in the process of smashing Yugoslavia. Vide: M. J evti ć Među narodne pretpostavke islamske transformacije u Bosni i Hercegovini, „Vojno Delo” 1993, br. 1-2; M. Jevtić, Panturkizam i njegova uloga u jugoslovenskoj krizi, ,Vojno Delo” 1994, br. 1-2.

${ }^{4}$ D. Tan a s ković, Neoosmanizam. Doktrina i spolno politička praksa, Beograd 2010, pp. 45-46.

${ }_{5}$ An interpretation concerning assimilative power of Ottoman Empire was presented by Albert Howe Lybyer, Albert H. Ly by er, Władanie Imperium Osmańskim w czasach Sulejmana Wspaniałego, Oświęcim 2015, p.12 et passim. Vide: H. In a l cik, The Ottoman Empire: The classical age, 1300-1600, London 1973.

${ }^{6}$ F. Cardin i, Europa a islam. Historia nieporozumienia, Kraków 2006, pp. 114-115.

${ }^{7}$ A. Muharemi, Turska. Uvod u povijest, unutarnju i vanjsku politiku, Zagreb 2012, p. 26. 
quering Asia Minor (Anatolia) in $1390^{\circ}$. Then, the Turkish people conquered part of the Albanian territory. In 1392, they captured Skopje in Macedonia, which became a centre of military and Islamization actions. The Ottomans conquered Bulgaria to the Danube and the western part of Serbiato Niš. Despite defeat in Ankara in 1402, where the Turkish army was defeated by Tamerlane, the Ottomans became a permanent element of the political and cultural situation in the Balkans ${ }^{9}$. When they had conquered the Serbian despotate in 1459 , they attacked the kingdom of Bosnia that was conquered in $1463^{10}$. In 1465, Turkey conquered Herzegovina. In 1468, Turkey conquered Albania and then Montenegro, but they never fully controlled these territories. Since 1468, the Padishah army was wreaking havoc in the Croatian territories, defeating the army of the Ban of Croatia in 1493. In 1521, Turkey captured Belgrade, and many cities in Dalmatia in the years $1522-1524^{11}$.

Contrary to popular belief, the Ottomans were rather not tolerant of other religions, they discriminated against Christians, the essence of their activity was not tolerance, but integration in the Muslim spirit ${ }^{12}$.

The Turkish domination of the Balkan shad weakened after the defeat of the Padishah army in the Battle of Vienna (1683). In the second half of the 19th century, many provinces of the Ottoman Empire were displeased with the insufficiency of reforms. In the beginning of the Great Eastern Crisis (1875-1878), superpowers in Western Europe were inclined to support the Padishah state so as not to break the world order, which would be caused by the collapse of the Ottoman giant, but at the end of the 19th century, they preferred the partition of Turkey, which was called the "sick man" of Europe ${ }^{13}$. The crisis of the empire, especially in the Balkans, was reflected by numerous rebellions and uprisings, which finally led to the end of the Turkish rule.

The official rule of the Padishah Empire in the Balkans ended definitively, as it was emphasized by Mieczysław Tanty, as a result of the Balkan wars 1912-1913, when desideratum "The Balkans for Balkan nations" was achieved ${ }^{14}$. Turkish historians, looking justification for the Ottomans, claimed that the rule of the Ottomans enabled conquered nations to develop, because their social order, language, religion and culture were maintained ${ }^{15}$. On the contrary, the rule of the Ottomans in the Balkans disturbed the development of this region and led to wars and conflicts of ethnic and religious origin.

${ }^{8}$ Imperial vision of Bayezid I said about the state from the Danube to the Euphrates. Capturing Constantino pleand conquering of the Middle Eastin the beginning of 16th century aimed at restoration of empire of Alexander the Great and conquering the whole world by the Ottomans, P. F od or, Nadludzki ciężar imperium. Osmanie w Europie Środkowej - nieudana próba stworzenia monarchii uniwersalnej (1390-1566), Oświęcim 2015, pp. 25-26; Vide: C. Fink e1, Osman's Dream. The story of the Ottoman Empire 1300-1923, New York 2005.

9 P. Wró b e 1, Krzyż i Pótksiężyc, Zachodnie Bałkany wobec Turcji w latach 1444-1463, Kraków 2000, p. 16.

10 J. Skow ronek, M. Tanty, T. Wasilew ski, Historia Stowian Poludniowych i Zachodnich, Warszawa 1988, p.147.

${ }^{11}$ Jugoslavenske zemlje pod turskom vlašću (do kraja XVIII stoljeća), eds. B. Đurđev, M. Vasić, Zagreb 1962, p. 36.

${ }_{12}$ M. S ivignon, Les Balkans. Une géopolitique de la violence, Paris 2009, p. 78.

13 Zygmunt S. Zalewski, Dardanele $i$ Gallipoli w polityce i strategii mocarstw europejskich podczas I wojny światowej, Olsztyn 2001, p. 13; T. A r o n s o n, Zwaśnieni monarchowie. Europejskie trony w przeddzień katastrofy 1914 roku, Kraków 2014, p. 135.

${ }^{14}$ M. Tanty, Bałkany w XX wieku. Dzieje polityczne, Warszawa 2003, p. 87.

15 E. B o y a r, Ottomans, Turks and the Balkans. Empire lost, relations altered, London-New York 2007, pp. 141-146. 


\section{Neo-Ottoman vision in Turkish foreign policy}

At the turn of the 20th and 21st century, Turkish politicians took actions to restore influences in the areas of the former Ottoman Empire. Ruling the pro-Islamic conservative Party of Justice and Development (AKP) set a new direction of foreign policy, the so-called "strategic depth" (from the Turkish: stratejik derinlik). This pragmatic strategy was developed under the influence of the principles of neo-Ottomanism that gained in importance during the rule of president Turgut Özal and prime minister Necmettin Erbakan ${ }^{16}$. A creator of this doctrine is Ahmet Davutoğlu, an adviser to the Prime Minister, Recep Tayyip Erdoğan, fulfilling the function of the minister of foreign affairs (2009-2014), and then of the Prime Minister (2014-2016) in the Turkish government. In general, "Strategic depth" means the increase in political activity of Turkey in the areas of the former Ottoman Empire: in the Middle East, the Balkans, Central Asia, Caucasus and in North Africa.

The current Turkish policy shows that Turkey wants to be a central state, and its strategic goal is not only membership in NATO and the EU, but to play the main role in major conflicts in the areas of the former empire, especially in the Middle East ${ }^{17}$.

Turkish economic growth is an important tool for the execution of foreign policy. Dated back to 2002, it is called the economic miracle and Turkey is regarded as a potential economic giant. In 2013, the Turkish economy was sixth in Europe and sixteenth in the world. According to forecasts of the World Bank and Goldman Sachs, the Turkish GDP growth should be greater until 2050 than the GDP growth of Italy and Canada. This success is mainly attributed to the ruling party - its economic reforms and the period of relative political stabilization ${ }^{18}$. In accordance with data of the exports from the OECD, Turkish economic growth is forecasted to increase to $3.6 \%$ in 2016 , which is the biggest growth among the OECD countries ${ }^{19}$.

\section{Turkish priorities in post-Yugoslavian areas}

The Balkans is the priority of Turkish foreign policy, because this region is treated by Turkish politicians as a part of the Turkish territory towards Europe. The Balkans is still an area of struggle between the superpowers for economic, political and cultural influences. The main goal of the Turkish politicians (according to their declarations) has become the intensification of common spheres of interests, as well as regional integration in many fields in order to stabilize the Balkan countries, particularly post-Yugoslavian countries ${ }^{20}$.

${ }^{16}$ A. S zy mań s ki, Polityka zagraniczna Turcji w latach 2007-2009: kontynuacja czy zmiana?, „Polski Przegląd Dyplomatyczny" 2009, nr 2, p. 47.

${ }^{17}$ M. Herbut, Turcja między Wschodem a Zachodem, [in:] Polityka zagraniczna. Aktorzy. Potencjały. Strategie, red. naukowa T. Łoś-Nowak, Warszawa 2011, p. 324.

${ }_{18}$ J. S a chs, The Secret Behind Turkey's Economic Miracle, 29.05. 2013, https://themoscowtimes.com/ articles/the-secret-behind-turkeys-economic-miracle-24440, [date accessed: 15.08.2016]; The Mint countries: Next economic giants?, http://www.bbc.com/news/magazine-25548060, [date accessed: 15.08.2016].

${ }_{19}$ Gross domestic productis also growing. In 2003, it amounted to 305 billion, and in 2015, 720 billion, I. Is a ković, Balkan predstavlja prioritet za Tursku (an interview with Ahmet Tuta, Turskich ambassador in Croatia), „Preporodov Journal” 2016, br. 186, travanj, pp. 28-29.

${ }^{20}$ Ibidem, p. 25. 
Ahmet Davutoğlu emphasized that his country can't move away from the Balkans - treated as a historical zone of the influence of Turkey ${ }^{21}$.

The most important example of regional cooperation is a mechanism of trilateral cooperation Turkey - Croatia - Bosnia and Herzegovina and Turkey - Serbia - Bosnia and Herzegovina, of which goal is the stabilization in the region. In 2010, Istanbul was a place of signing a declaration by the presidents of Turkey, Serbia, Bosnia and Herzegovina. According to this declaration, Turkey is the guarantor of stabilization in the Balkans ${ }^{22}$. Turkish politicians claim that their strategy in the Balkans consists of a few elements, which include: dialogue at the highest political level, providing security for both sides, maximal economic integration and multi-culturalism and multi-religiosity ${ }^{23}$.

The major investments in this area are made by Turkish TIKA, that is, the Turkish Cooperation and Coordination Agency. Its activity in post-Yugoslavian countries includes investments in the following fields: $45.5 \%$ in the field of healthcare, $20.49 \%$ in the field of management, $15.81 \%$ in the field of education, $14.78 \%$ in the field of culture and $3.45 \%$ in the field of water infrastructure. In the last two years, TIKA signed, among others, 50 agreements on the restoration of the Islamic Centre and other places of religious worship of Muslims in Croatia ${ }^{24}$. Turkish authorities claim that their activity in post-Yugoslavian countries are not only focused on the restoration of mosques. They also restore monuments of Christian culture, for example, the St. Đorđe Orthodox church in Kumanovo, Macedonia or the Franciscan monastery in Fojnica, Bosnia and Herzegovina ${ }^{25}$.

The relationship of Turkey with Muslim-majority countries (Bosnia and Herzegovina and Kosovo) has become particularly important ${ }^{26}$.

Bosnia and Herzegovina was a priority in Turkish policy during the civil war (19921995). Another spur to establish closer cooperation was the struggle against Iran for the influence on the Muslim environment. Turkey sent its military contingent, which was a part of UNPROFOR and, after signing the Dayton Agreement, took an active part in the following military missions: IFOR, SFOR and EUFOR. At present, Turkey is still helping to train soldiers of the Bosnia and Herzegovina army, supporting their transformation towards $\mathrm{NATO}^{27}$. Davutoğlu emphasized the fact that the territorial integrity of Bosnia and Herzegovina is as important for Turkey as its own independence, and the security of Sarajevo is as important as the security of Istanbul ${ }^{28}$. During his visit in Ankara in 2016, the Prime Minister of Bosnia and Herzegovina, Denis Zvizdić, announced an increase in trade exchange from USD 560 million to one billion. Erdogan emphasized that Turkey will always help Bosnia and Herzegovina. Economic cooperation is of multi-level nature. A free trade agreement between both countries was signed in 2007. Turkey invested EUR

${ }^{21}$ A. S zy mań s ki, Polityka zagraniczna Turcji..., pp. 47-50.

22 J. Kraj c arz, Turcja: bałkański „,neo-osmanizm” droga stabilizacji politycznej i gospodarczej, 27.04. 2012, balkanistyka.org/turcja-balkanski-neo-osmanizm-droga-stabilizacji-politycznej-i-gospodarczej/, [date accessed: 20.02.2016].

${ }^{23}$ I. I s a k o v i ć, Balkan predstavlja prioritet..., p. 25.

24 Ibidem, s. 31.

25 This organization also helped the victims of the flood in 2014 in Croatia, Ibidem, p. 26.

${ }^{26}$ Ibidem.

27 A. Muharemi, Turska..., pp. 225-226.

28 D. Tan a s ković, Neoosmanizam..., pp. 45-46. 
115 million until 2009 in this country ${ }^{29}$. Both countries also signed a cooperation agreement on military training ${ }^{30}$. Since the civil war, 460 mosques have been renovated and 370 new mosques have been built in Bosnia and Herzegovina with the share of capital from Islamic countries. Many mosques are currently in the phase of renovation ${ }^{31}$.

The domination of the Muslim community, which is the majority in Bosnia and Herzegovina (48.4\% of total population) has a negative impact on the development of the political system ${ }^{32}$. Ivica Mlivončić claimed that Bosnian Muslims long for the period of Turkish rule and Islamic order ${ }^{33}$.

Nevertheless, Kosovo, as a Muslim-majority country $(95.6 \%$ of the population are Muslims) is a particular example among post-Yugoslavian countries ${ }^{34}$. Turkey has well-developed political, economic and cultural relations with Kosovo. The authorities of Kosovo emphasize that Turkey is an important promotor of their country on the international arena. Kosovo's independence was recognized by Turkey the day following its declaration (February 18, 2008) $)^{35}$. Turkey quickly signed an agreement on visa liberalization with Kosovo. Turkey is also Kosovo's most important economic and trade investor ${ }^{36}$. Thanks to Turkish initiatives, the highway from the border to the Albanian Port Durrës was built, which gives Kosovo access to the sea. The Turkish company Limaks runs the airport in Priština. This company also takes an active part in building the highway from Priština to the Albanian border (in cooperation with U.S. companies) ${ }^{37}$.

Cooperation in the field of culture and education between both countries is successfully developing. More than 100 students from Kosovo are granted scholarships every year, which allows them to continue their education in selected Turkish universities. Turkey also gives money for the restoration of monuments of Ottoman culture, for example, the tomb of sultan Murad I, who died during Battle of Kosovo (1389) ${ }^{38}$.

Turkish politicians are also more and more focused on Macedonia, which is referred to by them as the heart of the Balkans. Turkish diplomacy thinks that security of the Balkans depends on the political situation in this country ${ }^{39}$. Therefore, Turkey signed an agreement on military cooperation, giving Macedonia security, even before commencement of peacekeeping missions under the aegis of the $\mathrm{EU}^{40}$. Turkey supports the member-

${ }^{29}$ A. Muharemi, Turska..., pp. 225-226.

${ }^{30}$ BiH i Turska žele udvostručiti robnu razmjenu, 8.04.2016, http://balkans.aljazeera.net/vijesti/bih-i-turska-zele-udvostruciti-robnu-razmjenu, [date accessed: 20.02.2016].

31 „Dnevni Avaz” (specijal), 6 maja 2016, p. 35.

32 D. G i ba s-Krzak, Bośnia i Hercegowina: determinanty dziejów..., pp. 196-200 et passim.

33 I. Mlivo n č ić, Al Qaida se kalila u Bosni i Hercegovini. Mjesto i uloga mudžahida u republici Hrvatskoj i Bosni i Hercegovini od 1991. do 2005. godine, Split-Mostar 2007, p. 107.

34 CIA, The World Factbook, Kosovo, 19 December 2016, https:/www.cia.gov/library/publications/resources/the-world-factbook/geos/kv.html, [date accessed: 20.02.2016].

35 According to outstanding researchers dealing with this issue, declaration of independence by Kosovo violated the Constitution of Republic of Serbia. It is also against the rules of international law, E. B u jwid-K u re k, Serbia w nowej przestrzeni ustrojowej. Dzieje, ustrój, konstytucja, Kraków 2012, pp. 92-93.

${ }^{36}$ A. Muharemi, Turska..., pp. 207-208.

37 Ibidem, s. 227.

38 Ibidem.

${ }^{39}$ Rast trgovinske razmiene Makedonije i Turske, 23.12.2014, http://balkans.aljazeera.net/vijesti/rast-trgovinske-razmjene-makedonije-i-turske, [date accessed:15.08.2016].

${ }^{40}$ A. Muharemi, Turska..., p. 221. 
ship of Macedonia in NATO, but also emphasizes the necessity of increasing economic cooperation. In 2010, Turkey and Macedonia signed a document on strategic cooperation. The meetings of politicians at the highest level take place almost every month. Turkish investments in Macedonia reached the level of EUR 1 billion 200 million in recent years ${ }^{41}$. In 2014, the trade exchange was EUR 356 million, but Turkish authorities think that this may increase to 800 million in the coming years. In 2014, the import of products to Turkey increased by $23.8 \%$ in comparison with 2013 and amounted to EUR 245 million. One of the largest Turkish investors is komapnia TAV (Tepe Akfen Vie), which participates in financing of many of the local investments. Among others, it invested EUR 110 million in the airports in Ohrid and Skopje. Turkish enterprise Cevhair holding is building four tower blocks in Skopje, worth EUR 300 million, whereas, Turkish bank Halal Banka took over Macedonian IK Bank for EUR 23 million in $2008^{42}$.

It must be emphasized however, that a majority of Turkish initiatives, mainly educational programs run by non-governmental organizations, are for the Albanian population. The funds for the conservation of monuments from the Ottoman period are also granted by Turkey. In 2014, Ahmed Davutoğlu, during his visit to Macedonia, emphasized that preserving Ottoman culture in Macedonia is very important for the Turkish people. Turkish people want to feel at home in Macedonia ${ }^{43}$. The Turkish influence on the Macedonian people is so strong that the authorities even try to limit the broadcasting of popular Turkish series, especially those referring to the period of magnificence of the former empire such as: "The Magnificent Century" or "The Magnificent Century: Sultana Kösem". They are afraid that Turkish inspirations and Ottoman tradition may dominate the native cultural legacy ${ }^{44}$.

The political relations with Serbia were regarded as the most difficult from among the post-Yugoslavian countries due to the support given by Turkey to NATO troops during air raids on Yugoslavia in 1999 and fast recognition of the independence of Kosovo. Bilateral relations only fully normalized in March 2009 thanks to the visit of the minister of foreign affairs of Serbia, Vuk Jeremic to Turkey, when politicians announced that: "Serbia and Turkey are the factors of peace and stability in the Balkans". In July 2009, during the visit of the Turkish foreign minister in Serbia, the relationships between both countries were defined as a "strategic partnership". The visit of Turkish president, Abdullah Gül in Serbia at the end of 2009 led to the intensification of political, economic and cultural cooperation between both countries. Moreover, the practice of regular meetings of the ministers of foreign affairs of Serbia, Turkey and Bosnia and Herzegovina was also introduced ${ }^{45}$. In April 2011, the presidents of Bosnia and Herzegovina, Turkey and Serbia met in Karađorđevo, where they discussed regional cooperation and problems related to European integration

${ }^{41}$ Rasttrgovinske razmiene Makedonije i Turske..., /balkans.aljazeera.net/vijesti/rast-trgovinske-razmjene-makedonije-i-turske, [date accessed: 15.08.2016].

42 Ibidem.

43 Ibidem.

${ }^{44}$ Turcja: Tureckie seriale już wkrótce znikna z ekranów telewizyjnych w Macedonii, 17 listopada 2012, http://balkanistyka.org/turcja-tureckie-seriale-juz-wkrotce-znikna-z-ekranow-telewizyjnych-w-macedonii/, [date accessed 15.08.2016].

${ }^{45}$ N. J eftić-Š a ř evi ć, Zapadni Balkan u projekciji „,Turske strateške vizije”, Octobar 2010, http:// www.doiserbia.nb.rs/img/doi/0025-8555/2010/0025-85551004691J.pdf, [ date accessed: 20.02.2016]. 
of post-Yugoslavian countries ${ }^{46}$. Political declarations were accompanied by economic agreements, the documents on technical and financial cooperation and in the field of social welfare were also signed.

It must be emphasized that the goal of the frequent visits of Turkish politicians is to exert influence on Muslim minority in Serbia. Erdoğan, opening the Turkish cultural centre in Sandzak, said that he hopes that contacts between both countries will be strengthened and that ethnic and religious tensions will $\mathrm{end}^{47}$. Among others, Turkish politicians took part in mediations between parties in Sandżak, in order to avoid ethnic animosities, as well as clashes between feuding Muslim communities in Serbia ${ }^{48}$. SDA Sandžaka (Democratic Action PartySandzak), which is the party of Bosniac (Muslim) minority, supports Erdoğan's policy ${ }^{49}$. This party claims that only Erdoğan's presidency guarantees the economic and democratic development of Turkey ${ }^{50}$. The Islamic Community of Serbia (Islamska Zajednica Srbije) keeps permanent contacts with Turkish institutions and its goal is not only economic cooperation, but also the renovation of monuments of Ottoman culture (Turkish baths from the 15 th century were recently renovated) $)^{51}$.

The improvement of political relations between Serbia and Turkey favours the development of economic cooperation. In the last fourteen years, Turkish entrepreneurs invested EUR 95 million in Serbia, treating this country as a gate to the European Union. Their intention is to export products via Serbia to Russia, that Serbia signed a free trade agreement with. In 2013, Serbia exported products worth EUR 145 million to Turkey, whereas, it imported products worth EUR 334 million $^{52}$.

Turkey actively cooperates with Croatia. Turkish companies achieve successes in the field of tourism, finances and the power industry. Turkish investments w Croatia amounted to EUR 500 million until 2015. Trade exchange between Turkey and Croatia amounted to USD 400 million $^{53}$. Many initiatives regard cultural cooperation. In 2016, the Turkish Cultural Centre in Zagreb was opened (Yunus Emre) ${ }^{54}$. In April 2016, Erdoğan participated in

${ }^{46}$ A. Muharemi, Turska..., p. 229.

47 Ibidem, p. 228.

48 In 2011, Turkish minister of foreign affairs, Davutoglu and Serbian minister of foreign affairs, Vuk Jeremić took part in mediations between Sandžak parties, A. Muharemi, Ibidem, s. 228-228. Vide: Vučič i Davutoglu saglasni: Srbija i Turska su pravi prijatelji, 28.12.2015, http://www.telegraf.rs/vesti/politika/1926336vucici-davutoglu-saglasni-srbija-i-turska-su-pravi-prijatelji, [date accessed: 15.08.2016]. Since 1993, the Islamic Community has been responsible for the religious life of Muslims in Serbia (Islamska zajednica u Srbiji), which was subject to Islamic Community in Bosnia and Herzegovina (Islamska zajednica u Bosni i Hercegovini). Some clerics were against subordination to Sarajevo. As a result, they overthrew Mufti Muamer Zukorlicin 2007 and established of new community with a headquarters in Belgrade, which was called the Islamic Community of Serbia (Islamska zajednica Srbije), K. K ujawa, Konflikt muzułmańsko-muzulmański w Serbii, 17.09. 2010, http://www.stosunki.pl/?q=content/konflikt-muzu\%C5\%82ma\%C5\%84sko-muzu\%C5\%82ma\%C5\%84ski-wserbii, [date accessed: 15.08.2016].

49 Podrška očuvanju demokratskih vrijednosti, 5.08. 2016, http://www.sda.rs/vijesti/1878-podrska-ocuvanju-demokratskih-vrijednosti.html, [date accessed: 15.08.2016].

50 Ibidem.

${ }^{51}$ Muftija Dudić primio delegaciju Vakufske direkcije iz Turske, 23.08.2016, http://mesihat.org/2016/08/23/ muftija-dudic-primio-delegaciju-vakufske-direkcije-iz-turske/, [date accessed: 15.08.2016].

52 Srbija i Turska žele bolje ekonomske odnose, 28.10.2014, http://balkans.aljazeera.net/vijesti/srbija-i-turska-zele-bolje-ekonomske-odnose, [date accessed: 15.08.2016].

53 I. I s a k o vi ć, Balkan predstavlja prioritet..., p. 31.

54 Ibidem, p. 25. 
the commemoration of the hundredth anniversary of the official recognition of Islam by the Croatian Parliament. Huseinef Kavazović, the Grand Mufti of the Islamic Community in Bosnia and Herzegovina claimed that Muslims treat Croatia as their own homeland, in which they can express both Muslim and European identity. The highest authorities of Croatia, including President Kolinda Grabar-Kitarović took part in the celebrations. One of the invited guests was Bakir Izetbegović, a member of the office of collective president in Bosnia and Herzegovina ${ }^{55}$.

\section{The threats resulting from neo-Ottoman policy: religious fundamentalism or terrorism?}

The cooperation in many fields between Turkey and post-Yugoslavian countries is developing Turkish influences in the Balkans and has an impact on the assertiveness of the Muslim community. However, it also leads to the mobilization of fundamentalist fractions of Muslim religion that can be connected with, in a direct or indirect way, the network of international terrorism. Some analysts claim that the civil war in the former Yugoslavia has created conditions for the development of Islam and its penetration in Western Europe, whereas, Islamic fundamentalists were allowed to build an operational and organizational infrastructure in the Balkans ${ }^{56}$. John Schindler, an American analyst, claimed that the Balkans may be a training base for radical Islamic terrorist organizations, whereas Bosnia and Herzegovina - just like Afghanistan in the 1980s - has already become a training centre for the Mujahedeen. Darko Trifunović paid attention to the fact that after the civil war in the former Yugoslavia, many "Allah warriors" remained in Bosnia and Herzegovina, contributing to the development of the terrorist network of radical Islamic groups in the western Balkans: in Bosnia and Herzegovina, Macedonia, Kosovo, Serbia (Sandzak) and Albania ${ }^{57}$.

Esad Hecimovic distinguished three groups connected with the Wahhabis, which operate in the areas of Bugojno, Sarajevo and northern Bosnia. Their potential may cause fights between the local followers of Islam, which may cause other ethnic conflicts, based on terrorist cells ${ }^{58}$.

Many facts concerning terrorist attacks in the 21 st century proves the activity of terrorists motivated by religious fundamentalism in post-Yugoslavian countries and their participation in attacks on the targets in Western Europe. In May 2007, six members of radical Islamic group (Albanians from Kosovo and Macedonia) were arrested in New Jersey on a charge of preparations for terrorist attacks on Fort Dix. In October of the same year, Asim Čejvanovic, a Bosniac, was arrested in the same place for preparations to attack on U.S. embassy in Vienna. In January 2010, New York police arrested a citizen of Bosnia and Herzegovina, who was a member of Al-Qaeda. The police found materials in his flat

\footnotetext{
${ }_{55}$ N. Botonjić, Svečana akademija u HNK, „Minber: Glasilo Islamske zajednice u Hrvatskoj” 2016, br. 9-10, pp. 41-43.

${ }_{56}$ S. Trifković, Turkey as regional power: neo-Ottomanism in action, "Politeia" 2011, br. 2, p. 91.

57 A. Wej ks zn er, Ewolucja terroryzmu motywowanego ideologia religijna na przykładzie salafickiego ruchu globalnego dżihadu, Poznań 2010, pp. 215-216 et passim.

${ }_{58}$ O. Ka r a be g, Koliko je vehabijski pokret jak u BiH, 28.08.2010, http://www.slobodnaevropa.org/content/most_koliko_jak_vehabizam_bih/2139765.html, [date accessed: 15.08.2016].
} 
for the production of explosives. He kept contact with the terrorists, who were suspected of preparations for the attack on the subway in New York on the anniversary of the World Trade Center attacks. In March 2011, an Albanian from Kosovo attacked American soldiers at Frankfurt airport, killing two of them ${ }^{59}$.

It is hard to say what is the actual activity ofterrorist cells operating in the western Balkans, particularly in post-Yugoslavian countries. Islamic terrorism is a complicated phenomenon. It was often generated by U.S. secret service in cooperation with mercenary companies, which organized training camps in Albania and Turkey for the Mujahedeen, and then redeployed them to Kosovo and Macedonia. Their task was to destabilizecountries founded after thecollapseof Yugoslavia ${ }^{60}$. However, the following hypothesis may also be formulated: the connections of Balkan fundamentalists with terrorist networks, which is now the army of Islamic State are still strong. In accordance with this paradigm, Bosnia and Herzegovina is a base for the return of sleeper agents, as well as "bedroom suburb for the terrorists" because it is difficult (unlike Western Europe) to control its territory.

The recent events confirm the threat of Islamic terrorism of Balkan provenance. In January 2015, ammunition and weapons from Bosnia and Herzegovina were used during the terrorist attack on "Charlie Hebdo" in Paris ${ }^{61}$. On November 18, 2015, two Bosnian soldiers were murdered in the suburbs of Sarajevo by the Wahhabis. Two days later, the car with Gen. Anto Jeleč, Chief of Armed Forces of Bosnia and Herzegovina, was attacked inside the Salakovac tunnel, near Mostar ${ }^{62}$. In April 2016, Bakir Izetbegović, a controversial politician ${ }^{63}$ said that religious extremism has developed in recent years in Bosnia and Herzegovina during the summit of Organization of Islamic Cooperation in Istanbul ${ }^{64}$.

The situation among Muslims in Macedonia is very tense, in which the Muslim populations is $33.3 \%$ of the total population ${ }^{65}$. The moderate fraction of Islam and the Wahhabis compete for power in Macedonia ${ }^{66}$. Macedonian authorities also admit that radical Islam poses a threat to state security and try to prevent it. The steps were taken to forbid the leader of a sect of Wahhabis to organize services and fulfil the function of an Imam. However, we don't know how strong the connections of the local Wahhabis are with the terrorist organizations that organize attacks in Western Europe ${ }^{67}$.

59 D. Trifun ović, Threat to international security - terrorism in South East Europe, [in:] Stużby specjalne $w$ systemie bezpieczeństwa państwa. Przeszłość - teraźniejszość - przyszłość. Materiały i studia, eds. A. Krzak and D. Gibas-Krzak, Szczecin 2012, Vol. II, pp. 296-297.

60 Ibidem.

${ }^{61}$ M. Ko k ot, Kto pomagał zamachowcom z „, Charlie Hebdo”? Trop prowadzi do Bośni i Hercegowiny, 2.01.2015, http://wyborcza.pl/1,76842,17293035,Kto_pomagal_zamachowcom_z_Charlie_Hebdo__Trop_ prowadzi.html, [date accessed: 15.08.2016].

${ }^{62}$ E. Feli ć, Napadi na pripadnike Oružanih Snaga Bosn i Hercegovine. Terorizamili ne?, "Preporodov Journal" 2015, Vol. 181, p. 30.

${ }^{63}$ Son of the president of Bosnia and Herzegovina, Alija Izetbegovicia is known for, among others, many unsolved misappropriations of funds from the period of the civil war and after the war, D. Gibas-Krzak, Bośnia i Hercegowina: determinanty dziejów..., p. 187 et passim.

${ }^{64}$ F. Al is pa h ić, Posrbljavanje bošnjačkog liderstva, „Preporodov Journal”, 2016, br. 186. p. 40.

${ }_{65}$ CIA, The World Factbook, Macedonia, 19 December 2016, https:/www.cia.gov/library/publications/ resources/the-world-factbook/geos/mk.html, [date accessed: 15.08.2016].

${ }^{66}$ I. S t a w o w y-K a w ka, Miejsce ludności muzulmańskiej w Macedonii..., p. 131.

${ }^{67}$ Bałkany coraz bardziej islamskie, 28.09.2010, https://euroislam.pl/balkany-coraz-bardziej-islamskie/, [date accessed: 15.08.2016]. 


\section{Conclusions and recommendations}

The Balkan vector of neo-Ottoman Turkish policy clearly indicates the growing intensification of political, economic and cultural contacts of Turkey with post-Yugoslavian countries. Common economic and political initiatives contribute to the development of these new countries. However, they may become dependent on a stronger partner, that is, Turkey. The Turkish economic miracle in the 21 st century is supposed to increase assertiveness and favours its ambitions to become a world power. Due to the unpredictable changes in an international order, neo-Ottoman tendencies may arouse anxiety. There are more and more arguments referring to the Ottoman legacy of the Balkans in the discourse of Turkish politicians. Many researchers are concerned that the goal of Turkish policy is the restoration of Pax Otomanain the areas of the former Turkish empire.

Although, it is difficult to give a clear answer to the question regarding the imperial tendencies of Turkey, the author of this article claims that this threat shouldn't be underestimated. By supporting such Muslim countries in the Balkans as: Albania, Kosovo and Bosnia and Herzegovina, Turkey can control them, affecting the strategic balance in this region. Is this a threat to the security of post-Yugoslavian countries in the Balkans? Giving a definite answer is not easy. However, taking the complexity of the ethnic and religious issues into consideration, which has generated numerous conflicts for ages, the development of neo-Ottomanism should be thoroughly observed.

\section{Bibliography:}

Alispahić F., Posrbljavanje bošnjačkog liderstva, „Preporodov Journal”, 2016, br. 186.

Aronson T., Zwaśnieni monarchowie. Europejskie trony w przeddzień katastrofy 1914 roku, Kraków 2014.

Batkany coraz bardziej islamskie, 28.09.2010, https://euroislam.pl/balkany-coraz-bardziej-islamskie/. BiH i Turska žele udvostručiti robnu razmjenu, 8.04.2016, http://balkans.aljazeera.net/vijesti/bih-i-turska-zele-udvostruciti-robnu-razmjenu.

Botonjić N., Svečana akademija u HNK, „Minber: Glasilo Islamske zajednice u Hrvatskoj” 2016, br. 9-10.

Bujwid-Kurek E., Serbia w nowej przestrzeni ustrojowej. Dzieje, ustrój, konstytucja, Kraków 2012.

Boyar E., Ottomans, Turks and the Balkans. Empire lost, relations altered, London-New York 2007.

Cardini F., Europa a islam. Historia nieporozumienia, Kraków 2006.

CIA, The World Factbook, Macedonia, 19 December 2016, https://www.cia.gov/library/publications/resources/the-world-factbook/geos/mk.html.

Deliso Ch., The coming Balkan Caliphate: the threat of radical Islam to Europe and the West, Westport, Connecticut-London 2007.

Efendić H., Mudžahedini u Bosni, Sarajevo 2007.

Elsässer J., Jak dżihad przybyt do Europy. Wojownicy Boga i tajne stużby na Bałkanach, Warszawa 2007.

Felić E., Napadi na pripadnike Oružanih Snaga Bosne i Hercegovine. Terorizam ili ne?, "Preporodov Journal" 2015, Vol. 181.

Finkel C., Osman's Dream. The story of the Ottoman Empire 1300-1923, New York 2005.

Fodor P., Nadludzki ciężar imperium. Osmanie w Europie Środkowej - nieudana próba stworzenia monarchii uniwersalnej (1390-1566), Oświęcim 2015.

Galijašević D., Era terorizma u BiH, Beograd 2007. 
Gibas-Krzak D., Bośnia i Hercegowina: determinanty dziejów. Pomiędzy Serbami, Chorwatami a supremacja Muzutmanów, Częstochowa 2016.

Herbut M., Turcja między Wschodem a Zachodem, [w:] Polityka zagraniczna. Aktorzy. Potencjały. Strategie, red. naukowa T. Łoś-Nowak, Warszawa 2011.

Inalcik H., The Ottoman Empire: The classical age, 1300-1600, London 1973.

Isaković I., Balkan predstavlja prioritet za Tursku (an interview with Ahmet Tuta, Turskich ambassador in Croatia), „Preporodov Journal” 2016, br. 186.

Jevtić M., Međunarodne pretpostavke islamske transformacije u Bosni i Hercegovini, „Vojno Delo” 1993, br. 1-2.

Jevtić M., Panturkizam i njegova uloga u jugoslovenskoj krizi, „Vojno Delo” 1994, br. 1-2.

Jeftić-Šarčević N., Zapadni Balkan u projekciji ,,Turske strateške vizije”, Octobar 2010, http://www. doiserbia.nb.rs/img/doi/0025-8555/2010/0025-85551004691J.pdf.

Jugoslavenske zemlje pod turskom vlašću (do kraja XVIII stoljeća), eds. B. Đurđev, M. Vasić, Zagreb 1962.

Karabeg O., Koliko je vehabijski pokret jak u BiH, 28.08.2010, http://www.slobodnaevropa.org/ content/most_koliko_jak_vehabizam_bih/2139765.html.

Kokot M., Kto pomagat zamachowcom z „, Charlie Hebdo”? Trop prowadzi do Bośni i Hercegowi$n y, 2.01 .2015$, http://wyborcza.pl/1,76842,17293035,Kto_pomagal_zamachowcom_z_Charlie_Hebdo__Trop_prowadzi.html.

Krajcarz J., Turcja: bałkański „,neo-osmanizm” droga stabilizacji politycznej i gospodarczej, 27.04. 2012, balkanistyka.org/turcja-balkanski-neo-osmanizm-droga-stabilizacji-politycznej-i-gospodarczej/.

Kujawa K., Konflikt muzutmańsko-muzulmański w Serbii, 17.09. 2010, http://www.stosunki.p1/?q= content/konflikt-muzu\%C5\%82ma\%C5\%84sko-muzu\%C5\%82ma\%C5\%84ski-w-serbii.

Lybyer Albert H., Władanie Imperium Osmańskim w czasach Sulejmana Wspaniałego, Oświęcim 2015.

Mlivončić I., Al Qaida se kalila u Bosni i Hercegovini. Mjesto i uloga mudžahida u republici Hrvatskoj i Bosni i Hercegovini od 1991. do 2005. godine, Split-Mostar 2007.

Muharemi A., Turska. Uvod u povijest, unutarnju i vanjsku politiku, Zagreb 2012

Muftija Dudić primio delegaciju Vakufske direkcije iz Turske, 23.08.2016, http://mesihat. org/2016/08/23/muftija-dudic-primio-delegaciju-vakufske-direkcije-iz-turske/.

Radulj S., Terroristička mreža u Bosni, Beograd 2007.

Sachs J., The Secret Behind Turkey's Economic Miracle, 29.05. 2013, https://themoscowtimes.com/ articles/the-secret-behind-turkeys-economic-miracle-24440.

Sivignon M., Les Balkans. Une géopolitique de la violence, Paris 2009.

Skowronek J., Tanty M., Wasilewski T., Historia Stowian Poludniowych i Zachodnich, Warszawa 1988.

Stawowy-Kawka I., Miejsce ludności muzułmańskiej w Macedonii-przemiany i perspektywy, „Prace Komisji Środkowoeuropejskiej PAU", 2014, Vol. XXII.

Szymański A., Polityka zagraniczna Turcji w latach 2007-2009: kontynuacja czy zmiana?, „Polski Przegląd Dyplomatyczny” 2009, nr 2.

Tanasković D., Neoosmanizam. Doktrina i spolnopolitička praksa, Beograd 2010.

Tanty M., Bałkany w XX wieku. Dzieje polityczne, Warszawa 2003.

Trifković S., Turkey as regional power: neo-ottomanism in action, "Politeia" 2011, br. 2.

Trifunović D., Threat to international security - terrorism in South East Europe, [w:] Stużby specjalne w systemie bezpieczeństwa państwa. Przeszłość - teraźniejszość - przyszłość. Materiały i studia, Vol. II., eds. A. Krzak and D. Gibas-Krzak, Szczecin 2012.

Wejkszner A., Ewolucja terroryzmu motywowanego ideologia religijna na przykładzie salafickiego ruchu globalnego dżihadu, Poznań 2010. 
Wróbel P., Krzyż i Półksiężyc, Zachodnie Bałkany wobec Turcji w latach 1444-1463, Kraków 2000. Zalewski Zygmunt S., Dardanele $i$ Gallipoli w polityce i strategii mocarstw europejskich podczas I wojny światowej, Olsztyn 2001.

\section{Danuta Gibas-Krzak}

\section{The Political, Economic and Cultural Influences of Neo-Ottomanism in Post-Yugoslavian Countries. An Analysis Illustrated with Selected Examples}

\section{Summary}

The goal of this paper is to show the expansion of the Turkish policy, defined as neo-Ottomanism, in the post-Yugoslavian countries, and its effect in the spheres of political, economic and cultural life. The author asks the questions: do Turkish influences contribute to the specific culture of European Islam, of which the goal, despite prevailing Islamophobia, is to disseminate ideals of tolerance between nations and religions? Does the Turkish capital contribute only to the economic development of post-Yugoslavian countries through investments? On the other hand, the reactivation of neo-Ottomanism may contribute to the development of radical tendencies, including religious fundamentalism, which is, in many aspects, a threat to post-Yugoslavian countries. More and more researchers and political experts claim that the political situation in the Balkans can be destabilized as a result of the domination of the Muslim environment, whereas the dissemination of radical versions of this religion such as Wahhabism may favour the development of Islamic terrorism. Firstly, Serbian researchers have a critical approach to this issue and they claim that neo-Ottomanism is of a revisionist nature, because it disturbs the political balance in the western Balkans resulting from the Dayton Agreement (1995).

Keywords: neo-Ottomanism, Islamic terrorism, Turkish policy, post-Yugoslavian countries, religious fundamentalism, the Balkans, economic influence, Islamization. 